\title{
The boundaries of governance in the post-modern world
}

JAMES KIRKBRIDE ${ }^{1}$

STEVE LETZA ${ }^{2}$

Liverpool John Moores University, UK

XIUPING SUN 3

Leeds Metropolitan University, UK

Clive Smallman ${ }^{4}$

Lincoln University, NZ

\begin{abstract}
$\underline{\text { Abstract }}$
We discuss the challenge of corporate governance and its regulation in the post-modern world. In so doing we explore the complex web of recent regulation that has developed out of a mix of political ideologies and business scandals. We highlight a series of identifiable issues at the interface between the regulation of corporations, its practice and its theory, and conclude with a discussion of future directions for governance research, as well as methodological issues implicit in process studies of governance.
\end{abstract}

\section{The challenge of corporate governance}

So frequent and damaging are corporate failures, ${ }^{5}$ or at least so it seems, it is almost a cliché to state that corporate governance is a critical legal, economic, managerial and societal issue. Under the precepts of capitalism and globalisation, defrauding, deceiving or ignoring the wishes of minority investors counters the received wisdom that investor protection is vital to financial development and economic growth. Fraudulent behaviour, deceit or the exposure of minority investors to self-interested directors, large shareholders or the markets, discourages participation, limits the availability of equity to firms dependent upon external finance, and so constrains financial growth. ${ }^{6}$ For example, one study found

1 Corresponding author: James Kirkbride is Professor of Law and Dean of the Faculty of Business and Law, Liverpool John Moores University, UK. His PhD is from Leeds Metropolitan University, UK. His research interests include business regulation, corporate governance, taxation and competition law. email: j.kirkbride@livjm.ac.uk.

2 Steve Letza is Professor of Corporate Governance at Liverpool John Moores University, UK. He received his PhD from Bradford University School of Management, UK. His research interests include corporate governance, operational risk management and corporate performance measurement.

3 Xiuping Sun is Lecturer in Business Strategy at Leeds Business School, Leeds Metropolitan University, UK. $\mathrm{He}$ received his PhD from Leeds Metropolitan University. His research interests centre on corporate governance and the application of process thought philosophy in business and management.

4 Clive Smallman is Professor of Business Management and Head of Business Management and Law in the Commerce Division, Lincoln University, New Zealand. His PhD is from Bradford University School of Management, UK. His research interests include operational risk management, corporate governance and process thinking.

5 G Probst and S Raisch "Organizational crisis: the logic of failure" (2005) 19(1) Academy of Management Executive 90-105.

6 C Mayer, "Corporate Governance: A policy for Europe" (paper presented at the Annual Congress of the Swiss Society of Economics and Statistics, University of Bern, 2003). 
that investors were willing to pay 18 per cent more, on average, for shares in American or British firms with "strong" corporate governance practices than for a firm in a similar competitive position, but with a weak governance profile. ${ }^{7}$ Moreover there is empirical evidence to support the contention that good corporate governance is significantly and positively associated with long-term shareholder wealth. ${ }^{8}$

Notwithstanding this economic imperative, the social and environmental irresponsibility of some corporations has seen the emergence of a large, vocal and, occasionally, violent protest movement, the central objects of whose wrath are company directors, regulators and legislators. Paradoxically, amongst the most devout capitalists there is a healthy body of opinion that shares the view of those they regard as "anarchists" in that they believe that the "malefactors of great wealth" must be reined in." Consequently, current corporate governance reforms are driven by both politics ${ }^{10}$ and shareholder activism. ${ }^{11}$

In this paper we examine, evaluate and criticise theories of corporate governance and approaches to its regulation. We identify a series of issues with governance and regulation. We suggest a series of important research themes based on our critique and propose an alternative "process" approach to researching and theorising in corporate governance.

\section{A short history of corporations and their governance}

\section{THE EARLY PRIMACY OF THE PUBLIC GOOD}

Governance in the public interest was the accepted doctrine in Western countries until the 19th century. Until then, it was the royal or state prerogative that gave "corporations" the right to conduct business, and private economic interests had no rights. Public stock corporations promising colonisation and the exploitation of the colonies' resources to the public benefit could petition the state for a charter. However, whilst individuals could own shares in corporations and sell them, serving shareholder interests was not the primary purpose of corporations. ${ }^{12}$

The Dutch East India Company was the first corporation to be granted the right of perpetual existence in 1623, followed by the British East India Company in $1654 .{ }^{13}$ In both cases, fully transferable shares were the principle mechanism of ownership, but central to their charters was the ". . . integral purpose of serving public interests". ${ }^{14}$ In 17 th and 18thcentury America, entrepreneurs adopted similar corporate forms in establishing enterprise around property speculation, primary industries, utilities and transport, ${ }^{15}$ although these early corporations were few in number and closely regulated ${ }^{16}$ Notwithstanding this tight

7 P Coombes and M Watson, “Three surveys on corporate governance” (2000) McKinsey Quarterly, 74, 75-6.

8 M Anson, T White and H Ho, "Good corporate governance works: more evidence from CaIPERS" (2004) 5(3) Journal of Asset Management 149.

9 I M Stelzer, “The corporate scandals and American capitalism” (2004) 154 Public Interest 19-31, 31.

10 P A Gourevitch, “The politics of corporate governance regulation” (2003) 112(7) Yale Law Review 1829-80.

11 G Carriere, A Cowen, J A Marco, D Monson, F Pievani and T Rasker, European Corporate Governance: A changing landscape, 50th Anniversary Research Project October Celebrations (Cambridge, MA: MIT Sloan School of Management, 2002), pp. 7-16.

12 M M Blair, Reforming Corporate Governance (Georgetown: Georgetown University Law Centre, 2003), pp. 14-20; J Hood, "Do corporations have social responsibilities?" (1998) 48(11) The Freeman 680-4.

13 Blair, Reforming Corporate Governance (n. 12 above), p. 15.

14 J A Cohan, “'I didn't know' and 'I was only doing my job’: has corporate governance careened out of control? A case study of Enron's information myopia" (2002) 40 Journal of Business Ethics 275-99, 292.

15 Blair, Reforming Corporate Governance (n. 12 above), pp. 14-15.

16 Hood, "Do Corporations" (n. 12 above). 
control over this small group, the incorporation (through special legislative act) of enterprise was further developed in the early 18th century as a means of

... holding property for some public, charitable, educational, or religious use, so that such property could not be owned by the individuals who . . . might be managing the organization or charged with making decisions about the use of the property ...17

\section{THE PRIMACY OF SHAREHOLDER RIGHTS}

Following independence, American states extended the notion of corporation to selfincorporation, although it remained fixed upon the provision of the public good. However, at the turn of the 18th century, self-incorporation under some states' corporate laws allowed the emergence of firms whose central purpose was to make money for their shareholders - a new governance paradigm had emerged. This concept went largely unchallenged until the case of Dodge v Ford Motor Company. ${ }^{18}$ The court held that even Henry Ford was accountable to the shareholders of "his" motor company, and could not make stakeholders in the company benefactors over and above shareholders. ${ }^{19}$ The court did make it clear that corporate benefaction could pass legal scrutiny provided that it had a legitimate relationship to corporate profits, and this finding was codified in subsequent cases. Whilst the primary case law is restrictive, the law built upon it does give corporate managers great discretion. However, this case established the precedent that corporations are directly responsible only to shareholders.

This principle came under threat during the Great Depression. For example, General Electric (GE) promoted stakeholders' interests (shareholders, employees, customers and the general public) as a means of surviving the slump. ${ }^{20}$ The rationale for GE's approach was that shareholders' long-run profit could be enhanced by satisfying the needs and expectations of other stakeholders. ${ }^{21}$ This and other examples led to the initiation of the shareholder:stakeholder dialectic that continues to this day, characterised by the respective positions that corporations were either "responsible only to their stockholders" 22 or "must not only profit [their] stock holder[s], but must also engage in social service". 23 The former position held and still holds sway with the judiciary, whilst the latter, with its strong societal foundations predating Dodge v Ford Motor Company, found favour with popular opinion, and still does. The debate turns upon the interpretation of what constitutes the "fiduciary responsibility" of management. To advocates of shareholder primacy this seems to mean placing trust in managers to maximise return on investment solely in the best interests of shareholders. To advocates of stakeholder primacy this is anathema, since they hold fiduciary responsibility to encompass not just private, but public trust. An alternative view is that the representation of economic value added or market value added, as shareholder value, is not complete, since it does not take into account the consequences for all

17 Blair, Reforming Corporate Governance (n. 12 above), p. 20.

18170 NW 668, Michigan Supreme Court, 1919.

19 Hood, "Do Corporations" (n. 12 above).

20 L E Preston and H J Sapienza, "Stakeholder management and corporate performance" (1990) 19(4) Journal of Behavioral Economics 361-75.

21 H Hummels, "Organizing ethics: a stakeholder debate" (1998) 17(13) Journal of Business Ethics 1403-19.

22 Cohan, "I didn’t know" (n . 14 above), p. 292; A A Berle, "Corporate powers as powers in trust" (1931) 44 Harvard Law Review 1049; A A Berle, "For whom corporate managers are trustees: a note" (1932) 45 Harvard Law Review 1365.

23 Cohan, "I didn't know" (n. 14 above), p. 292; E M Dodd, "For whom are corporate managers trustees?" (1932) 45 Harvard Law Review 1145. 
stakeholders, as demanded by the efficiency principle. ${ }^{24}$ Moreover, this focus is not compatible with the conceptualisation of a firm as a nexus of contracts, since insisting on the primacy of shareholders excludes any number of additional and imported contracts with stakeholders. ${ }^{25}$ Paradoxically, one of the chief protagonists in the early debate went on to highlight the passivity of 1930s shareholders, who, in effectively abdicating control and responsibility to managers, "surrendered the right that the corporation should be operated in their sole interest". 26

\section{THE RESURGENCE OF STAKEHOLDERS}

As corporations grew, a supplement to the shareholder argument emerged, as some authorities argued that the increased size and power over society of corporations meant that their social responsibilities needed to be reassessed. In the controversial case of Smith Manufacturing Cov Barlow, ${ }^{27}$ shareholders challenged a donation made by managers to Princeton University. In finding in favour of Smith Manufacturing, the court held that the shareholders

whose private interests rest entirely upon the well-being of the corporation, ought not to be permitted to close their eyes to present-day realities and thwart the long-visioned corporate action in recognizing and voluntarily discharging its high obligations as a constituent of our modern social structure. ${ }^{28}$

This decision and others, as well as new state statutes, recognised the legitimacy of corporate philanthropy, implicitly endorsing calls for the primacy of other social goals above the claims of shareholders. From the 1960s through to the 1980s, the stakeholder concept was popular among consumerists, environmentalists and social activists. Corporate executives also used it as a defence against takeovers in the 1980s. For example, in the case of Paramount Communications v Time Inc, ${ }^{29}$ the court allowed Time's directors to reject Paramount's takeover offer even though that offer maximised shareholders' financial value, denying the absolute primacy of the shareholder model. This was followed in Credit Lyonnaise Bank v Pathe Communications Corporation, ${ }^{30}$ when the court further promoted the stakeholder model on the basis that the directors do not owe duties to any single interest group but to the corporation as a whole and the community of interests that the corporation represents. This reinvigorated the primacy of stakeholders. ${ }^{31}$

\section{EUROPEAN CORPORATE GOVERNANCE}

Corporate governance systems across Europe vary. In Britain and Ireland, common-lawbased corporate law enforces a regime similar to that in North America. Herein the emphasis is on the firm as a legal entity largely beholden to its investors. In continental Europe, enterprise law dominates, focusing upon the enterprise as an economic or social unit, and so explicitly including its stakeholders. However, it is ambiguous in its

24 P Milgrom and J Roberts, Economics, Organization and Management (London: Prentice Hall, 1992).

25 G Charreaux and P Desbrières, "Corporate governance: stakeholder value versus shareholder value" (2001) 5 Journal of Management and Governance 107-28.

26 A A Berle and G C Means, The Modern Corporation and Private Property (New York: Macmillan, 1932).

2797 A 2d 186 and 98 A 2d 581, New Jersey 1953.

28 Hood, "Do corporations" (n. 12 above).

29 571A 2d 1140, Delaware Chancery Court, 1989.

30 WL 277613, Delaware Chancery Court, Dec 30, 1991.

31 M M Blair, Ownership and Control: Rethinking corporate governance for the twenty-first century (Washington DC: Brookings Institution, 1995). 
definition of "stakeholder", 32 although it includes mandatory protections for employees, creditors and even shareholders notably absent from US state law or appearing only in the federal securities regime. ${ }^{33}$

However, despite this fundamentally different legal base, a longitudinal study of British managerial mindsets undertaken between 1980 and 2000 indicated a sharp increase of managerial emphasis on stakeholder interests and a drop of emphasis of shareholder values in 2000 compared with those in 1990. Most of the managers attached importance to stakeholders in 2000 compared with only 50 per cent in $1980 .{ }^{34}$ Arguably this does not represent an absolute predominance of stakeholder forces, real managerial consideration or intrinsic moral value in business operations, as the stakeholder theorists often claim. Evidence shows that British stakeholder groups' influence on and care over corporate reports and performance did not increase, but in fact decreased between the 1970s and the early 1990s. ${ }^{35}$ Large empirical investigations also suggest that corporate social performance does not necessarily result in positive corporate financial performance. ${ }^{36}$ In fact, massive media coverage largely influenced the socially perceived importance of stakeholders' interests in the 1990 s due to academic and political concerns about the issue of corporate social responsibility, short-termism and the negative consequences of the takeover movement in the 1980 s. ${ }^{37}$

In continental Europe, the enterprise system effectively confers concentrated ownership by banks and other institutions. As a consequence, stakeholder relations are commonly complex. The health of their lending relationship (occasionally to the detriment of shareholder value) is generally cemented by their holding of seats upon the boards of their clients. Governments or labour unions, in pursuit of economic or social goals, often exert considerable power and influence over management. This negotiated balance, between shareholder and other stakeholder interests, is arguably offset by issues around accountability, transparency and flexibility, ultimately leading to alleged difficulties in response to changing competitive conditions. ${ }^{38}$

Governance in continental Europe, like general management ${ }^{39}$ is also further divisible between Germanic firms (headquartered in Germany, the Netherlands, Scandinavia, Switzerland and Austria) and Latin firms (France, Belgium, Italy, Spain, Portugal and Greece). Germanic governance is characterised by the heavy involvement of banking officials in

32 E Wymeersch, "Elements of comparative corporate governance in Western Europe", in M Isaakson and R Skog (eds), Aspects of Corporate Governance (Stockholm: Juristforlaget, 1994); H W De Jong, "The governance structure and performance of large European corporations" (1997) 1(1) Journal of Management and Governance 5-27; S S Rehman, Competitiveness and Corporate Governance in the EU (Washington, DC: George Washington Center for the Study of Globalization, 2004).

33 W Carney, "The political economy of competition for corporate charters" (1997) Journal of Legal Studies 26; D J Greenwood, Democracy and Delaware: The puzile of corporate law (Utah: University of Utah, College of Law, 2003), pp. 309, 320-5.

34 R Mansfield, M Poole and P Mendes, Two Decades of Management (London: British Institute of Management, 2001).

35 S Letza and C Smallman, "Est in aqua dulci non invidiosa voluptas. In pure water there is a pleasure begrudged by none" (2001) 12(1) Critical Perspectives on Accounting 65-85.

36 J Griffin and J F Mahon, "The corporate social performance and corporate financial performance debate" (1997) 36(1) Business and Society 5-32.

37 E Berglof, "Reforming corporate governance: redirecting the European agenda" (1997) 12 Economic Policy 91-123; A Gamble and G Kelly, "Shareholder value and the stakeholder debate in the UK" (2001) 9(2) Corporate Governance 110-17.

38 Rehman, Competitiveness (n. 32 above).

39 R Calori and F Seidel, "The dynamics of management systems in Europe", in R Calori and P de Woot (eds), A European Management Model: Beyond diversity (London: Prentice Hall, 1994), pp. 55-78. 
corporate decision-making, employee influence on business policy, and the role of a limited number of dominant shareholders, who exert considerable influence on management.

Latin corporations are marked by even larger and more dominant shareholders as well as some bank influence. They also form strong networks or financial groups. There is generally little employee influence, with highly trained management operating in strict hierarchies, lacking the consensual decision-making of Germanic firms. ${ }^{40}$

\section{A corroding chain of regulatory reform?}

Given the convoluted legislative background, the enduring failure of legislators, professional bodies and corporate governance theorists to develop coherent regulatory and governance models that explain and highlight opportunities equitably to constrain corporate or market excess to the satisfaction of business and society is, perhaps, of little or no surprise. Post-modern business life is increasingly complex, ${ }^{41}$ and opportunities for corporate fraud, the abuse of managerial power, and social and environmental irresponsibility are manifold. Worldwide legislators and regulators have moved to curb illegal, immoral and amoral boardroom behaviours. ${ }^{42}$ In America since the late 1980s, a series of reforms has altered the role and number of independent, non-executive directors; split the dual role of chief executive officer (CEO) and chair; and limited the role of executive directors in determining their own compensation. ${ }^{43}$ Additionally, scandals at Enron, Worldcom and others ${ }^{44}$ have forced the hand of the authorities and the SarbanesOxley $\mathrm{Act}^{45}$ has changed the governance landscape with its requirement for improved corporate accountability, stringent disclosure, an increased role for independent directors, and a much higher profile for auditors and the Audit Committee. ${ }^{46}$ Moreover, the New York Stock Exchange ${ }^{47}$ and the American Stock Exchange ${ }^{48}$ have each changed their listing requirements to emphasise the importance of the independence of non-executive directors and their role in corporate governance, audit and compensation committees. As a consequence, boards in the US are undergoing considerable change in leadership,

40 De Jong, "The governance structure” (n. 32 above).

41 U Beck, The Brave New World of Work, P Camiller (trans.), (Cambridge: Polity Press, 2000); C B Carter and $\mathrm{J}$ W Lorsch, Back to the Drawing Board: Designing corporate boards for a complex world (Cambridge, MA: Harvard Business School Press, 2004), pp. 15-39.

42 A Florini, "Business and global governance: the growing role of corporate codes of conduct" (2003) 21(2) Brookings Review 4-8.

43 Carter and Lorsch, Back to the Drawing Board (n. 41 above), p 2.

44 C L Wade, "Corporate governance failures and the managerial duty of care" (2002) 76(4) St John's Law Review 767.

45 Public Law 107-204, 107th Congress, enacted 30 July 2002.

46 M E Clark, "Hamstrung or properly calibrated? Federalism and the appropriate role of government in the post-Sarbanes-Oxley world" (2004) 1(4) International Journal of Disclosure and Governance 385; P-M Boury and C M Spruce, "Auditors at the gate: section 404 of the Sarbanes-Oxley Act and the increased role of auditors in corporate governance" (2005) 2(1) International Journal of Disclosure and Governance 27; R Romano, "The Sarbanes-Oxley Act and the making of quack corporate governance" (2005) 114(7) Yale Law Journal 1521; M Toda and W McCarty "Corporate governance change in the two largest economies: what's happening in the US and Japan?" (2005) 32(2) Syracuse Journal of International Law and Commerce 189; M Yakhou and V P Dorweiler, "Corporate governance reform: impact on accounting and auditing" (2005) 5(1) Corporate Governance 39.

47 NASDAQ, Summary of NASDAQ Corporate Governance Proposals 1 (2003); NYSE, Amendment No. 1 to the NYSE's Corporate Governance Rule Proposals (New York: New York Stock Exchange, 2002); NYSE, Corporate Governance Rule Proposals Reflecting Recommendations from the NYSE Corporate Accountability and Listing Standards Committee, as approved by the NYSE Board of Directors (New York: New York Stock Exchange, 2002).

48 AMEX, Enhanced Corporate Governance Rules (SR-Amex-2003-65) (New York: American Stock Exchange, 2003). 
membership and performance evaluation. The potential effects of these changes are not yet fully understood, ${ }^{49}$ leaving a number of questions about board effectiveness unanswered. ${ }^{50}$

In Europe, a significant number of influential proposals, reports and codes have been produced in recent years in an attempt to resolve corporate governance issues. ${ }^{51}$ Overall there is a trend to independent oversight. For example, the role of non-executive directors on onetier boards was considerably strengthened by the French Revised Principles of Corporate Governance ${ }^{52}$ and the British Combined Code. ${ }^{53}$ The reform continues in both countries, with an ongoing debate between bodies representing different elements of French industry 54 and further research into the role of non-executive directors in Britain. ${ }^{55}$ There is also a perceptible trend towards the adoption of distinct CEO and board chairs, ${ }^{56}$ the effectiveness of which is disputed. ${ }^{57}$ The heightened strategic profile of German supervisory boards marks an attempt to employ an important property of Anglo-American singular boards. ${ }^{58}$ However, German corporate governance remains firmly grounded in co-determination, just as France is constitutionally obliged to maintain its flexible model of labour participation. These circumstances mean that higher standards of independence may be difficult to achieve. Across wider Europe that common theme is the conduct of audit committees. ${ }^{59}$

49 Romano, "The Sarbanes-Oxley Act" (n. 46 above).

50 E E Lawler and D L Finegold, "The changing face of corporate boards" (2005) 46(2) MIT Sloan Management Review 67.

51 K J Hopt, Modern Company and Capital Market Problems: Improving European Corporate Governance after Enron, Law Working Paper 05/2002 (Brussels: European Corporate Governance Institute, 2002); K J Hopt and P C Leyens, Board Models in Europe. Recent Developments of Internal Corporate Governance Structures in Germany, the United Kingdom, France and Italy, Law Working Paper 18/2004 (Brussels: European Corporate Governance Institute, 2004).

52 Vienot I, The Boards of Directors of Listed Companies in France (Paris: Conseil National du Patronat Français \& Association Française des Entreprises Privées, 1995); Vienot II, Report on the Committee of Corporate Governance (Paris: Association Française des Entreprises Privées \& Mouvement des Entreprises de France, 1999); D Bouton (chair), Promoting Better Corporate Governance in Listed Companies (Paris: Association Française des Entreprises Privées \& Mouvement des Entreprises de France, 2002).

53 A Cadbury (chair), Report of the Committee on the Financial Aspects of Corporate Governance (London: Gee, 1992); R Greenbury (chair), Directors Remuneration, report of a study group chaired by Sir Richard Greenbury (London: Gee, 1995); R Hampel (chair), Corporate Governance, report of a committee chaired by Sir Ronald Hampel (London: Gee, 1998); N Turnbull, Internal Control: Guidance for directors on the Combined Code (London: The Institute of Chartered Accountants in England and Wales, 1999).

54 AFEP and MEDEF, The Corporate Governance of Listed Corporations: Principles for corporate governance based on consolidation of the 1995, 1999 and 2002 AFEP and MEDEF's reports (Paris: Association Française des Entreprises Privées \& Mouvement des Entreprises de France, 2003); AFG, Recommandations sur le gouvernement d'entreprise (Paris: L'Association Française de la Gestion Financière, 2004).

55 D Higgs, Review of the Role and Effectiveness of Non-Executive Directors (London: Department of Trade and Industry, 2003); K G Corley, "Examining the non-executive director's role from a non-agency theory perspective: implications arising from the Higgs report" (2005) 16(s1) British Journal of Management S1-4.

56 Hopt and Leyens, Board Models (n. 51 above).

57 J W Lorsch and A Zelleke, "Should the CEO be the chairman?" (2005) 46(2) MIT Sloan Management Review 71.

58 T Baums, Corporate Governance Rules for Quoted German Companies (Frankfurt am Main: German Panel on Corporate Governance, 2000); G Cromme, German Corporate Governance Code (Düsseldorf: Government Commission, 2002); G Cromme, German Corporate Governance Code (Amended) (Düsseldorf: Government Commission, 2003).

59 Hopt and Leyens, Board Models (n. 51 above); R Smith, Audit Committees Combined Code Guidance (London: Financial Reporting Committee, 2003). 
At the European Union level the European Commission has commissioned a series of consultative documents ${ }^{60}$ and is in the process of implementing an action plan ${ }^{61}$ that "devotes special attention to a series of corporate governance initiatives aiming at boosting confidence on capital markets". 62

Another general policy objective is the development of a corporate governance regime that improves productivity and encourages innovation. ${ }^{63}$ However, as is the norm in Europe, considerable disagreement over the nature of corporate governance is staying the hand of reformers. The major issue relates to firm and territory: should firms operate under the regulations of the country in which they are registered and have their headquarters or should they be obliged to meet the demands of the country where the majority of their operations are based? 64 Furthermore, the principle of "subsidiarity", 65 which allows EU Member States to implement pan-European directives as they see fit, also allows them considerable latitude in the implementation of so-called "common" standards. 66

Outside the European Union, following a number of scandals, the Swiss Business Federation, Economiesuisse, and the Swiss Stock Exchange published codes of best practice and guidelines on corporate governance. ${ }^{67}$ Elsewhere codes of corporate governance have been introduced across the developed and developing world, for example, in Korea, ${ }^{68}$ Japan, ${ }^{69}$ and in Australia. ${ }^{70}$

In Japan, governance reform was partly initiated by high-profile scandals, but more so by the need to improve decision-making and to reform operations and organisational structures in order to remain competitive with China, Europe and the US. Shareholder structures have also changed of late, with institutional investors and individuals now holding sway above the formerly dominant keiretsu. ${ }^{71}$

Each of these corporate governance initiatives is undoubtedly well intended and well founded. Each aims, to varying extents, to enhance corporate governance, improve duties and standards of care, and level the international trade playing field, among other objectives.

60 E.g. J Winter, J M Garrido Garcia, K J Hopt, J Rickford, G Rossi, S Christensen and J Simon, Report of the High Level Group of Experts on a Modern Regulatory Framework for Company Law in Europe (Brussels: Commission of the European Communities, 2002).

61 DG Internal Market, Synthesis of the Responses to the Communication of the Commission to the Council and the European Parliament: "Modernizing company law and enhancing corporate governance in the European Union - a plan to move forward", COM (2003) 284 final of 21 May 2003, Internal Market Working Document (Brussels: Commission of the European Communities, Directorate General, 2003).

62 EC, "Company law and corporate governance: Commission presents Action Plan", press release IP/03/716 (Brussels: European Commission, 2003).

63 EC, Progress on Financial Services (10th Report). Turning the corner: preparing the challenge of the next phase of European capital market integration (Brussels: European Commission, 2004).

64 D Wójcik, Convergence in Corporate Governance: Empirical evidence from Europe 2000-2003, WPG 04-19 (Oxford: Oxford University Economic Geography Research Group, 2004), p. 1.

65 K v Kersbergen and B Verbeek, "Subsidiarity as a principle of governance in the European Union" (2004) 2(2) Comparative European Politics 142-62.

66 S Spivey, "Corporate governance and the role of government" (2004) 1(4) International Journal of Disclosure and Governance 307, 311-12.

67 SWX, Directive on Information Relating to Corporate Governance (Corporate Governance Directive, DCG), 1 July (Zurich: Swiss Exchange, 2002); SWX, Commentary re Corporate Governance Directive (Zurich: Swiss Exchange, 2004).

68 J-C Kim, Code of Best Practice for Corporate Governance (Seoul: Committee on Corporate Governance, 1999).

69 TSE, Principles of Corporate Governance for Listed Companies (Tokyo: Tokyo Stock Exchange, 2004).

70 ASX Corporate Governance Council, Principles of Good Corporate Governance and Best Practice Recommendations (Sydney: Australian Stock Exchange, 2003).

71 Toda and McCarty, "Corporate governance change" (n. 46 above), pp. 191-2, 199. 
Each has to some extent had some impact on financial efficiency, investors' risk, corporate oversight and ultimately on competition. However, the scandals still occur, companies (even the seemingly successful) still file for bankruptcy ${ }^{72}$ and there is much to be said against poor regulation and its attendant costs - particularly those accruing to investors and the public. Moreover, regulatory costs to firms are considerable, ${ }^{73}$ and there is a great deal of discontent with some reforms, particularly in Britain, amongst senior industrialists. Of recent British reforms, the Higgs Report ${ }^{74}$ has been singled out as "ludicrous" and a "new high in lows" with its recommendations for raising the profile of non-executive directors. The report is further criticised for its "one-size-fits-all" template. ${ }^{75}$ This illustrates the endless controversy over the balance between laissez-faire and strict regulation. Can governance and governance regulation in its orthodox form allow firms to operate effectively whilst defending minority investors and the public good and simultaneously allowing the markets to make money?76

\section{ISSUES WITH THE GOVERNANCE ORTHODOXY}

Perhaps the single major legal issue with the current orthodoxy is that under current corporate law worldwide, corporations may cut costs (and increase profit) at the expense of the public good. ${ }^{77}$ A clear example of this is the case of Yorkshire Water (a British utility), which, in spite of faltering service quality in the mid-1990s, continued to guarantee dividends to its shareholders. ${ }^{78}$ At the limit, the share maximising principle implies that directors should "violate the rules when it is profitable to do so". ${ }^{79}$ In Miller v American Telephone \& Telegraph, ${ }^{80}$ the court found that illegal acts, whilst committed to benefit the corporation through its future value, may amount to a breach. ${ }^{81}$ Permissive limited liability law invites corporations to externalise costs; without such encouraging law, directors might be less inclined to take advantage of them. In continental Europe, the law provides mandatory protection for employees, creditors and shareholders. However, this does not seem to have inconvenienced the more committed corporate criminals.

In its current form, corporate law informs how managers make value judgments, relating principally to share value maximisation at the cost of other values, and corporate governance and its regulation founders because of this. This is because governance models reduce the complexity of judgment in governance almost to the absurd: either

72 Probst and Raisch, "Organizational crisis" (n. 5 above).

73 I P Dewing and P O Russell, "Post-Enron developments in UK audit and corporate governance regulation" (2003) 11(4) Journal of Financial Regulation and Compliance 309-22; Mayer, "Corporate Governance" (n. 6 above); R H Gifford and H Howe, "Regulation and unintended consequences" (2004) 74(6) CPA Journal 6-9; Stelzer, "Corporate scandals" (n. 9 above).

74 Higgs, Role and Effectiveness (n. 55 above); Corley, "Examining the non-executive director's role” (n. 55 above).

75 Dewing and Russell, "Post-Enron developments" (n. 73 above); R V Aguilera, "Corporate governance and director accountability: an institutional comparative perspective" (2005) 16(s1) British Journal of Management S39-53.

76 Gourevitch, "The politics" (n. 10 above).

77 G Lenssen, L V D Berghe and C Louche, "Responding to societal expectations" (2005) 5(3) Corporate Governance 4.

78 Letza and Smallman, "Est in aqua" (n. 35 above), p. 69.

79 F H Easterbrook and D R Fischel, "Antitrust units by targets of tender offers" (1982) 80(6) Michigan Law Review 1155-78; F H Easterbrook and D R Fischel, The Economic Structure of Corporate Law (Cambridge, Mass: Harvard University Press, 1991), pp. 37-8.

80507 F 2d 759, 1974.

81 K Greenfield, “Ultra vires lives” (2001) 87(7) Virginia Law Review 87, 1279-379, 1291-5. 
shareholder value maximisation or stakeholder benefit maximisation; and this has been so since at least the $1930 \mathrm{~s} .{ }^{82}$

Corporate governance scandals are generally cast as economic crises. Hence, the regulatory drive focuses primarily on economic and the associated financial regulation. However, this primary focus does not appear adequately to acknowledge the "true" organisation and function of the post-modern economy and society, nor does it accommodate the formation and mutation of values and preferences that occur in and between individuals and institutions. Values including, but additional to, wealth maximisation are partly endogenous to economic and legal systems, and economic and legal systems and their performance are partly functions of people's values. ${ }^{83}$ Economy and society are irrevocably interconnected ${ }^{84}$ and feed off and build upon each other's experiences. ${ }^{85}$ By this argument corporate governance is not simply about the economic allocation of wealth, it is fundamentally about political choice. ${ }^{86}$ And here is the fundamental weakness of current theories, in that their focus is on wealth maximisation or distribution in an abstract and fallacious world of markets and property, with perfect information; it is not on decision-making in the real, complex, uncertain and value-laden post-modern world of organisations, and people.

The shareholder perspective recognises the single identity and personality of the corporation, which reinforces the private property rights of the shareholder and a "nexus of contracts" approach. The conceptualisation of the corporation as an individual either reduces the firm to the individuals who comprise it (the aggregate theory of corporate personality) or defines the firm as an individual itself (entity theory). Paradoxically, these inherently contradictory conceptions have the view of the firm as an "institution" in need of protection from government, in order that they may in turn protect civil society and citizens. ${ }^{87}$ The contractual conceptualisation of the firm defines corporations as "private entities of concern mainly to those who do business with them", 88 and is grounded in the

82 M A O’Sullivan, Contests for Corporate Control (New York: Oxford University Press, 2000); A Kakabadse and N Kakabadse, The Geopolitics of Governance (Hampshire: Palgrave, 2001); A Friedman and S Miles, "Developing stakeholder theory" (2002) 39(1) Journal of Management Studies 1-21; P R P Coelho, J E McClure and J A Spry, "The social responsibility of corporate management: a classical critique" (2003) 18(1) Mid-American Journal of Business 15-24; P R P Coelho, J E McClure and J A Spry, "The social responsibility of management: a reprise" (2003) 18(2) Mid-American Journal of Business 51-5; Greenwood, "Democracy and Delaware" (n. 33 above); F R Post, "A response to "the social responsibility of corporate management: a classical critique" (2003) 18(1) Mid-American Journal of Business 25-35; F R Post, "The social responsibility of management: a critique of the shareholder paradigm and defense of stakeholder primacy" (2003) 18(2) Mid-American Journal of Business 57-61; C Smallman, "Exploring theoretical paradigms in corporate governance" (2004) 1(1) International Journal of Corporate Governance and Ethics 27-94; X Sun, S R Letza, M Dibben and C Smallman, "Theories of Corporate Governance: A Critical Perspective" (paper presented at the Australian and New Zealand Academy of Management, University of Otago, Dunedin, New Zealand, 2004).

83 A Ben-Ner and L Putterman (eds), Economics, Values and Organization (Cambridge: Cambridge University Press, 1998).

84 B Kim and J E Prescott, "Deregulatory forms, variations in the speed of governance adaptation and firm performance" (2005) 30(2) The Academy of Management Review 414-25.

85 M R Dibben and C Smallman, "Ignoring Convention? Reframing process thinking in organizational analysis" (paper presented at the First Organization Studies Summer Workshop on Theorizing Process in Organizational Research, Santorini, Greece, 2005) at: www.egosnet.org/journal/dibben_smallman_ignori1.pdf (accessed 19 October 2005).

86 Greenwood, "Democracy and Delaware" (n. 33 above).

87 A De Tocqueville, Democracy in America, A Goldhammer (trans.) (New York, NY: Library of New York, 1835/2004).

88 Greenwood, "Democracy and Delaware" (n. 33 above), p. 5. 
principle that "because the choices [of firms] do not impose costs upon strangers to the contracts, what is optimal for the firms and investors is optimal for society". ${ }^{89}$

Hence, the corporation becomes a construct of multiple contracts, which are played out on some market or another. Our issue with this conceptualisation is, once more, that it is too simple. Real world contracts are not truly and fully negotiated between equals. Rather, involvement in contract may be unconscious (or at best partly conscious). Contract terms are not generally negotiated but are given or assumed, and even the most well-negotiated contracts cannot guarantee that they will not impose costs on strangers. ${ }^{90}$ The key in governance through contract is its reliance on perfect markets which do not exist in reality. Moreover, by nature of their construction at a point in history, rather than the present, contracts are always incomplete. ${ }^{91}$ Simply, the writing of a truly comprehensive contract is prohibitively costly since it is impossible to account for all future eventualities at the time of drafting, ${ }^{92}$ negotiate with all interested parties (hence conscious and unconscious involvement), construct the content in a way that it will always be enforceable, ${ }^{93}$ and gather all information relevant to the contract.

The conception of the corporation as property (an asset or thing owned by an individual or group) focuses upon agency theory ${ }^{94}$ whereby agents manage property on behalf of their principals (the owners); but do they act in the best interests of their principals? There are two key problems with this concept: organisations are comprised of physical and intangible assets (intellectual property), but what binds these assets together in a social network is not defined; and in law shareholders do not generally have the rights ordinarily associated with the role of owner (or principal). Consequently, "the . . agents lack a principal and the corporate property lacks an owner ... protecting the corporation does not protect the humans associated with it . ..".95

Agency theory also asserts that individuals will only work towards organisational goals that serve their own economic interests. However, it is persuasively arguable that "in successful organizations, workers identify with the organization ... [and] they take on the organization's objectives as their own". 96

Hence, based on the limitations of neoclassical economics: “. . . [any explanation of] organizational behavior solely in terms of agency . . . [which] ignore[s] key organizational mechanisms like authority, identification and coordination . . [is] . . . seriously incomplete". ${ }^{97}$

Our issue with the economic orthodoxy in respect of corporations is its focus on resource allocation, the concept of the firm as a production function and its macro-analytic approach. Perhaps this economic conceptualisation of the firm might be better served by an examination through the "lens of contract" which better focuses upon gains from trade,

89 Easterbrook and Fischel, The Economic Structure (n. 79 above), p. 6.

90 G Gilmore, Death of Contract (Columbus, Ohio: Ohio State University Press, 1974).

91 Blair, Reforming Corporate Governance (n. 12 above), p. 65.

92 O E Williamson, “The institutions of governance” (1998) 88(2) American Economic Review 75-9.

93 O Hart, "Corporate governance: some theory and implications" (1995) 105 The Economic Journal 678-89.

94 K M Eisenhardt, "Agency theory: an assessment and review" (1989) 14(1) Academy of Management Review 57-74; S Ghosal, "Bad management theories are destroying good management practices" (2005) 4(1) Academy of Management Learning and Education 75-91; J Hendry, "Beyond self-interest: agency theory and the board in a satisfying world" (2005) 16(s1) British Journal of Management S55-63.

95 Greenwood, "Democracy and Delaware" (n. 33 above), p. 7.

96 J E Stiglitz, "Symposium on organization and economics" (1991) 5(2) Journal of Economic Perspectives 15-24.

97 H A Simon, "Organizations and markets" (1991) 5(2) Journal of Economic Perspectives 25-44. 
conceives the firm as a governance structure, and takes "a more micro analytic construction . . . more amenable to the lessons of organization theory". 98

Conflating elements of these concepts exacerbates their fundamental weaknesses. For example, the property model conflicts with the market model because agents as fiduciaries work to an ethical code other than that of the contractual market place ${ }^{99}$ In spite of all of these issues, the shareholder model supports the principal-agent relationship and the s. 14 (UK Companies Act 1985) contract position, which takes a narrow perspective on directors' duties clearly identifying the separation of ownership and control and the primary position of seeking to enhance shareholder value. Moreover, limited liability firms are protected, and thus the shareholder model is a conflation, however flavoured, of all these concepts of the corporation. Given all of this, it "... is most curious that despite the lack of both face validity and empirical support, agency theory continues to dominate academic research on corporate governance". ${ }^{100}$

The stakeholder position allows for a broad range of stakeholder interests and responsibilities. These could include interests of employees, a broader social entity measure in the application of directors' duties, and a social stewardship influence on the role of nonexecutive directors and on the nature and duration of CEO contracts. However, in essence, stakeholder theory is an argument for admitting more contractual arrangements (for example, with employees), more principals ${ }^{101}$ and more individuals to the body corporate. Stakeholder theory "simply" expands the financial notion of share into a much broader sense of "joint experience", 102 so multiplying the problems of shareholder theory, since:

A manager told to serve two masters (a little for the equity holders, a little for the community) has been freed of both and is answerable to neither. Faced with a demand from either group, the manager can appeal to the interests of the other. ${ }^{103}$

For some authorities, ${ }^{104}$ the shareholder:stakeholder choice represents polarised positions. They believe that, in reality, a wider range of intermediate models exist, such as a finance model, a stewardship model, a stakeholder model and a political model. However, others disagree and suggest that these splinter groups are merely aspects of the main two models. ${ }^{105}$ Whatever the "truth", it is clear that current analyses of corporate governance focus on evaluating and judging the superiority of these main models and are often falsely

98 O E Williamson, "Examining economic organization through the lens of contract" (2003) 12(4) Industrial and Corporate Change 917-42.

99 Meinhard v Salmon, 249 NY 458, 1928.

100 Ghosal, "Bad management" (n. 94 above), p. 81.

$101 \mathrm{~J}$ Heath and W Norman, "Stakeholder theory, corporate governance and public management: what can the history of state-run enterprises teach us in the post-Enron era?" (2004) 53 Journal of Business Ethics 247-65.

102 Smallman, "Exploring theoretical paradigms" (n. 82 above); M Bonnafous-Boucher, "Some philosophical issues in corporate governance: the role of property in stakeholder theory" (2005) 5(2) Corporate Governance 34.

103 Easterbrook and Fischel, The Economic Structure (n. 79 above).

104 Blair, Ownership and Control (n. 31 above); J P Hawley and A T Williams, "Corporate Governance in the United States: The rise of fiduciary capitalism - a review of the literature" (first prize in LENS 1996 Corporate Governance Paper Competition); K Keasey, S Thompson and M Wright, "Introduction: the corporate governance problem - competing diagnoses and solutions", in K Keasey, S Thompson and M Wright (eds), Corporate Governance: Economic and financial issues (Oxford: Oxford University Press, 1997).

105 S R Letza and X Sun, "Corporate governance: paradigms, dilemmas and beyond” (2002) 2(1) Poznan University Economic Review 43-59. 
partisan or antagonistic. ${ }^{106}$ This reveals a substantial problem with current corporate governance theorising, since dominant theories describe and analyse only a few governance forms, ${ }^{107}$ and reflect neither ". . . the observed variety in economic life" 108 nor the interaction between industry, government and society, ${ }^{109}$ and do not allow for cultural influences on government. ${ }^{110}$

\section{Conclusion}

In this article we have discussed the challenge of corporate governance and its regulation in the post-modern world. We began by exploring the history of corporations and their governance, and established the differences between Anglo-Saxon (US, Britain and Ireland), continental European and other systems of governance. These different approaches essentially revolve around legal systems and national cultures.

We have also explored the miasma of recent regulation that has developed out of a mix of political ideologies and business scandals. This has contributed to the development of a global wave of corporate governance reform, the substantive effects of which are not yet clear. The issue here is that developing practice or regulation, with a paucity of knowledge about real process and grounded in ideology, is fraught with problems relating to imbalanced assumptions about people and institutions, leading from bad theory to poor practice. ${ }^{111}$

We then highlighted a series of identifiable issues at the interface between the regulation of corporate governance, its practice and its theory. Our analysis shows that no single model or structure of corporate governance and its regulation can work at all times since: "We do not have a perfect choice between market and hierarchy, we only have a choice between imperfect markets and imperfect hierarchies as well as imperfect combinations of both."112

Moreover, the dialectic theoretical orthodoxy is at best questionable. ${ }^{113}$ Recognition of these issues, alongside the changing nature of economy and society, suggests that we need to rethink corporate governance theory and that, in so doing, we must move beyond the conventional static ${ }^{114}$ and poorly contextualised models that have dominated to date. ${ }^{115}$

106 Simon, "Organizations" (n. 97 above); Charreaux and Desbrières, "Corporate governance” (n. 25 above); DTI, Modern Company Law for a Competitive Economy: Final report (London: Department of Trade and Industry, 2001); Coelho et al., "The social responsibility: a classic critique" (n. 82 above); Coelho et al., "The social responsibility: a reprise" (n. 82 above); Post, "A response" (n. 82 above); Post, "The social responsibility" (n. 82 above);. Heath and Norman, "Stakeholder theory" (n. 101 above).

107 A Pye and A Pettigrew, "Studying board context, process and dynamics: some challenges for the future" (2005) 16(s1) British Journal of Management S27-38.

108 A Grandori, "Governance structures, coordination mechanisms and cognitive models" (1997) 1(1) Journal of Management and Governance 29-47, 29.

109 A Midttun, "Policy making and the role of government: realigning business, government and civil society: emerging embedded relational governance beyond the (neo) liberal and welfare state models" (2005) 5(3) Corporate Governance 159; P Smith Ring, G A Bigley, T D'Aunno and T Khanna, "Perspectives on how governments matter" (2005) 30(2) The Academy of Management Review 308-20.

110 P Cornelius, "Good corporate practices in poor corporate governance systems: some evidence from the Global Competitiveness Report” (2005) 5(3) Corporate Governance 12.

111 Ghosal, "Bad management" (n. 94 above).

112 C Wolf, Markets and Governments (Cambridge, MA: MIT Press, 1988).

113 Ghosal, "Bad management" (n. 94 above); D C Hambrick, "Just how bad are our theories?" (2005) 4(1) Academy of Management Learning and Education 104-7; J Pfeffer, "Why do bad management theories persist? A comment on Ghosal" (2005) 4(1) Academy of Management Learning and Education 96-100.

114 C F Sabel, "Beyond principal-agent governance: experimentalist organizations, learning and accountability" (2004) Wetenschappelijke Raad Voor Het Regeringsebeleid 154-88.

115 M Huse, "Accountability and creating accountability: a framework for exploring behavioural perspectives of corporate governance" (2005) 16(s1) British Journal of Management S65-79. 
To conclude, we discuss future directions for governance research and methodological issues in studying governance and finish with some parting thoughts on the importance of a process approach to governance theorising.

\section{Future research directions}

The first issue in corporate governance research we highlight stems from our limited understanding of what goes on inside boardrooms and in directors' minds. Both the stakeholder and shareholder models focus upon external impacts based around a static view of the corporate entity. Neither model looks at the process of governing as the evolving sum of experiences ${ }^{116}$ of those who govern.

Perhaps, an approach that focuses upon process will allow the research community to understand fully and properly the complexities of governing, and to assess the implementation of best practice or deep causation in decision making (particularly in crisis-prone corporations).

A second research direction lies in the area of developing a deeper understanding of directors' knowledge, experience and skills, and the effects of these upon behaviour, particularly in decision-making processes. Some of this type of research has occurred, but its findings, whilst valuable, are limited by methodology focused on variance analysis and, as such, are far from definitive or significant. Such research is also important if we are to build a picture of the state and nature of the "talent pool".

A third important research direction is regulation. We have a comprehensive descriptive understanding of regulatory regimes, but we have no means of assessing the value or effectiveness of differing regimes other than through comparative research, which is sadly often "hijacked" by ideological posturing. Moreover, regulation thus far has been largely the province of legal, political, economic and financial scholars. Whilst this work is valuable, it is perhaps past time for organisational analysts to assess the managerial implications of differing regulatory regimes and, particularly, the processes of different forms of regulation and their roles as change vectors. More specifically in regulation, we need to take a look at the process of legislative analysis, design and development, perhaps taking lessons from the creativity and innovation literature? We also need to look at the interaction and roles of regulators, particularly seeking understanding of the structure of institutional power, and a conception of governance regulation that facilitates rather than prescribes or controls.

Fourth, there is a requirement for a comparative and comprehensive assessment of cultural influences on governance and whether or not the drive towards convergence in regulation and corporate governance practice is warranted.

Finally, whatever research direction we follow as corporate governance researchers, we cannot continue to fail to take context into account in our work, especially where we are dealing with corporate governance at its interface with society.

Research in corporate governance requires an approach that will clarify similarities and differences among theories, in order to facilitate theoretical integration and to generate a comprehensive understanding of governance. This requires a rigorous epistemological base, ${ }^{117}$ built upon an ontology that is more in keeping with

116 Dibben and Smallman, "Ignoring Convention" (n. 85 above).

117 Ghosal, "Bad management” (n. 94 above); Hambrick, “Just how bad are our theories?” (n. 113 above); Pfeffer, "Why do bad management theories persist?", (n. 113 above). 
understanding governing processes. We argue that the requirement is for an approach that accommodates a "fluxful", changeable and emergent post-modern world, emphasising reality as inclusively processual. ${ }^{118}$

118 A N Whitehead, Process and Reality (Cambridge: Cambridge University Press, 1929/1978); N Rescher, Process Metaphysics (Albany, NY: State University of New York Press, 1996); R Chia, "A Processual Perspective on Corporate Governance" (paper presented at the British Academy of Management Annual Conference, 2001); $\mathrm{H}$ Tsoukas and R Chia, "On organizational becoming - rethinking organizational change" (2002) 13 Organization Science 567-82; Dibben and Smallwood, “Ignoring Convention?” (n. 85 above). 
